\title{
The effect of a low-calorie diet with and without fenfluramine, and fenfluramine alone on the glucose tolerance and insulin secretion of overweight non-diabetics
}

\author{
J. RANALD W. DyKeS \\ M.B., Ch.B., B.Sc. \\ Department of Chemical Pathology, The University of Leeds
}

\begin{abstract}
Summary
Glucose tolerance and insulin secretion have been measured in six overweight non-diabetic subjects on first presentation and after 5 weeks of fenfluramine treatment without dietary restriction. There was a significant improvement in glucose tolerance and a marginally significant decrease in insulin secretion.

In another six overweight non-diabetic subjects, insulin secretion and glucose tolerance were measured on first presentation, after 10 weeks of low-calorie diet, and then after a further 10 weeks of the same low-calorie diet with the addition of fenfluramine. Diet alone did not produce any significant effect on glucose tolerance, but did bring about a significant decrease in insulin secretion. The addition of fenfluramine to the dietary therapy was associated with a marginally significant improvement in the glucose tolerance and a highly significant decrease in insulin secretion. This further decrease in insulin secretion was significantly greater than the decrease produced by diet alone in these six subjects.
\end{abstract}

\section{Introduction}

Obesity in non-diabetics is known to be associated with high insulin secretion in response to glucose (Yalow et al., 1965; Bagdade, Bierman \& Porte, 1967; Nikkilä \& Taskinen, 1971). Weight reduction through low-calorie diet decreases the hyperinsulinism (Salans, Knittle \& Hirsch, 1968; Farrant, Neville \& Stewart, 1969; Kalkhoff et al., 1971) and improves glucose tolerance (Farrant et al., 1969; Kalkhoff et al., 1971).

Fenfluramine, a non-addictive therapeutic agent chemically related to amphetamine, has appetitedepressing activity (Munro, Seaton \& Duncan, 1966) and is used together with dietary control in the treatment of obesity since it produces a greater loss in weight than other anorexigenic amphetamines (Craddock, 1969). An indication that fenfluramine might have a further action in addition to its appetite-depressing property arose when von Herold, Kemper \& Opitz (1965) recorded that the drug brought about a reduction of the blood glucose concentration in rats. Subsequently, using the forearm preparation of Butterfield \& Holling (1959), several workers have shown that intra-arterial infusion of the drug increases the uptake of glucose and oxygen by muscle independently of alteration in blood flow (Whichelow et al., 1971; Turtle, Burgess \& Bauckham, 1971).

Carbohydrate metabolism has been further investigated in obese non-diabetic subjects by studying the effect of fenfluramine alone and as an aid to dietary treatment, on glucose tolerance and insulin secretion.

\section{Patients and methods}

Six obese non-diabetic subjects had a baseline oral glucose-tolerance and insulin-secretion test before and then 5 weeks after treatment with fenfluramine. $40 \mathrm{mg}$ fenfluramine was given twice daily to four of the patients, the remaining two receiving $20 \mathrm{mg}$ twice daily and $60 \mathrm{mg}$ twice daily respectively.

Baseline oral glucose-tolerance and insulin- 8 secretion tests were carried out on another six obese non-diabetic subjects who were then treated for ac period of 10 weeks with low-carbohydrate, lowcalorie diet. A second oral glucose-tolerance and insulin-secretion test was performed at the end of this time. Fenfluramine $\mathbf{4 0} \mathrm{mg}$ twice daily was then added to the treatment and the subjects continued on the diet plus fenfluramine for a further period of 10 weeks; a third oral glucose-tolerance and insulinsecretion test was then carried out.

All the subjects were more than $10 \%$ overweight as calculated from the height and ideal weight tables issued by the American Society of Actuaries, 1959.

\section{Normal controls}

A normal range of insulin secretion was obtained from twenty-one normal individuals (eight males and thirteen females) age range 36-63 years. Each had a normal oral glucose-tolerance test, was within $5 \%$ of his or her ideal body weight and had none of the associations of the prediabetic state (large babies, family history, etc.). In order to establish the reproducibility of measurement of the parameters being studied, oral glucose-tolerance and insulin-secretion tests were repeated on eleven of these normal subjects (six males and five females).

\section{Laboratory estimations}

For at least 4 days before the initial oral glucosetolerance and insulin-secretion test, each subject had eaten a diet containing at least $200 \mathrm{~g}$ carbohydrate/ 
day. Each test was carried out as follows: after the fasting venous blood specimen was taken, each subject ingested $50 \mathrm{~g}$ glucose in $400 \mathrm{ml}$ water within $3 \mathrm{~min}$. Venous blood specimens were taken at 15, 30, $60,90,120$ and $150 \mathrm{~min}$ for glucose and insulin assay. Urine specimens were collected immediately before, and at 1 and $2 \mathrm{hr}$ after the glucose ingestion, and were tested semi-quantitatively for sugar content by Clinitest tablets. All subjects fasted for $13 \mathrm{hr}$ prior to each test. Fenfluramine was withdrawn for 13-15 hr before each test.

The specimens were assayed for glucose by the AutoAnalyzer glucose oxidase method of Morley, Dawson \& Marks (1968), the coefficient of variation being $4.6 \%$ at a blood glucose concentration of $105 \mathrm{mg} / 100 \mathrm{ml}$. Plasma immuno-reactive insulin was measured in duplicate by the method of Hales \& Randle (1963) using radioactive iodinated insulin and Oxoid membrane filters supplied by the Radiochemical Centre, Amersham. The pre-precipitated antibody and standard human insulin were supplied by Burroughs Wellcome. The standard deviation of the assay method was (a) $\pm 2.92 \mu \mathrm{U} / \mathrm{ml}$ for 115 duplicate determinations of $0-49 \mu \mathrm{U} / \mathrm{ml}$, (b) \pm 6.51 $\mu \mathrm{U} / \mathrm{ml}$ for 64 duplicate determinations of $50-99$ $\mu \mathrm{U} / \mathrm{ml}$ and (c) $\pm 7 \cdot 25 \mu \mathrm{U} / \mathrm{ml}$ for 55 duplicate determinations of $100-200 \mu \mathrm{U} / \mathrm{ml}$. If a plasma insulin concentration $>200 \mu \mathrm{U} / \mathrm{ml}$ was found, it was diluted to $<200 \mu \mathrm{U} / \mathrm{ml}$, and then re-assayed. Otherwise all specimens from one subject were determined in the same batch.

\section{Statistical methods of comparison}

The area under the glucose-tolerance test curve from 0 to $2 \frac{1}{2} \mathrm{hr}$ was measured as an index of glucose tolerance (Burns et al., 1965; Bagdade et al., 1967); a decrease in the area represents an improvement in glucose tolerance. Insulin secretion was estimated by the area under the plasma insulin curve from 0 to $2 \frac{1}{2} \mathrm{hr}$ (Perley \& Kipnis, 1965). The highest figure obtained for insulin secretion from these normal controls was $5003 \mu \mathrm{U}-\mathrm{min} / \mathrm{ml}$. All the obese subjects studied secreted quantities of insulin greater than this on first clinical presentation.

In order to compare the glucose-tolerance index and insulin secretion from each test on each patient with the results from the test immediately preceding, it was necessary to take account of the amount of change due to variation in estimation of the parameters. To obtain an assessment, the difference between the two glucose-tolerance indices from each of the eleven normal subjects on whom the oral glucose-tolerance test was repeated, was expressed as a percentage of the mean of the two indices. In the obese patients, the difference between the glucosetolerance indices of two consecutive tests was expressed as a percentage of the mean of the two indices. Similar percentages were calculated for the differences in the respective insulin secretions. Knowing the reproducibility of the test as shown by the eleven normal controls, the probability that the changes in glucose tolerance and insulin secretion were due to random variation in the estimation of these parameters was calculated. This was done by statistically comparing the patients' percentages with those from the controls by the non-parametric Mann-Whitney U-test described by Sokal \& Rohlf (1969).

The results on the obese patients on fenfluramine alone were compared with the reproducibility results on the eleven subjects.

The results on the obese patients on diet plus fenfluramine were compared with: (1) the reproducibility results on the eleven normal subjects, (2) the changes in the results due to diet alone for the first 10 weeks in the same obese subjects.

\section{Results}

Figures 1 and 2 show on a semi-logarithmic scale the actual glucose tolerance and insulin secretion of: (a) twenty-one normal subjects, (b) the eleven normal subjects on whom a repeat test was performed and (c) twelve obese non-diabetic subjects, baseline and after therapy. Table 1 demonstrates the statistical significance of dietary therapy alone and diet-plusfenfluramine on these parameters.

\section{Discussion}

Treatment of six obese non-diabetic subjects with fenfluramine alone was associated with a significant improvement in glucose tolerance and a marginally significant decrease in insulin secretion $(0.1>$ $P>0.05$ ).

Treatment of a further six subjects for 10 weeks on low-calorie diet alone produced weight-loss in all cases, a significant decrease in insulin secretion $(0.05>P>0.02)$ but no significant change in glucose tolerance. Addition of fenfluramine to the dietary treatment for a further period of 10 weeks in these subjects produced further weight-loss in all cases, a marginally significant improvement in glucose tolerance $(0.1>P>0.05)$ and a further and highly significant decrease in insulin secretion $(P<0.02)$ when the results were compared with the reproducibility of estimation of the parameters in normal subjects (see Table 1). When the results on the six subjects on diet-plus-fenffuramine during the second period of 10 weeks were compared with those on the same six subjects on diet alone for the first period of 10 weeks, there was no significant effect of the addition of fenfluramine on the glucose tolerance, but the drug did produce a further significant decrease in insulin secretion over the decrease produced by diet alone $(\boldsymbol{P}=0.05)$ (see Table 1$)$. In fact the insulin 


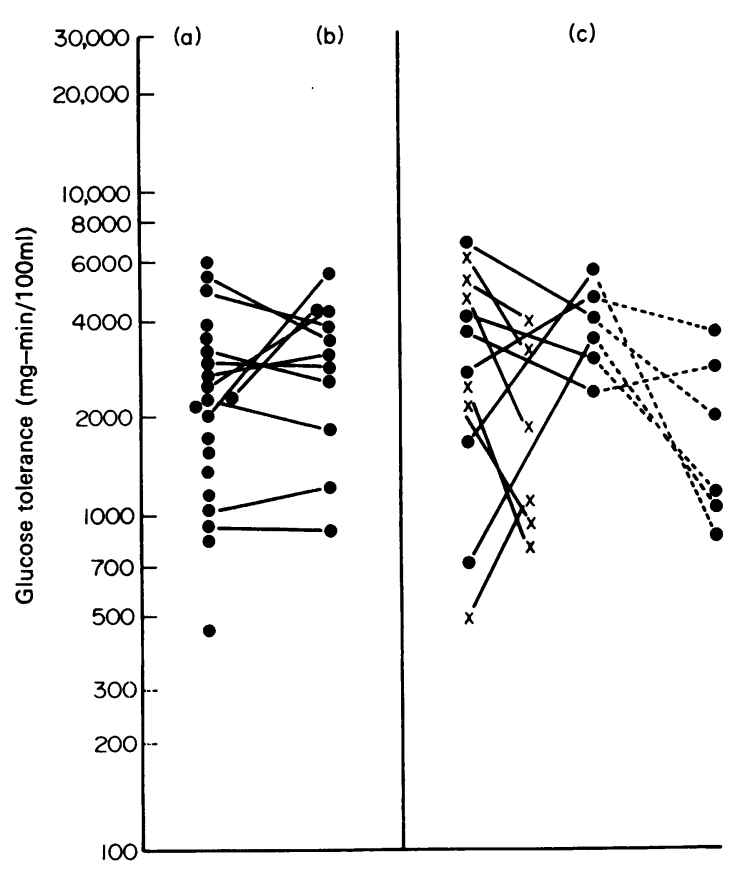

Fig. 1. Glucose tolerance of: (a) twenty-one normal subjects, (b) the eleven normal subjects on whom a repeat test was performed, (c) twelve obese non-diabetic subjects baseline and after therapy. - - diet alone;.... , diet plus fenfluramine; $\times \longrightarrow$, fenfluramine alone.

secretion in three of the subjects was reduced to within the normal range, i.e. $<5003 \mu \mathrm{U}-\mathrm{min} / \mathrm{ml}$ (Fig. 2).

Farrant et al. (1969) studied nine obese nondiabetic subjects and found that they lost from between 9 and $61 \mathrm{~kg}$ in body weight in a period of

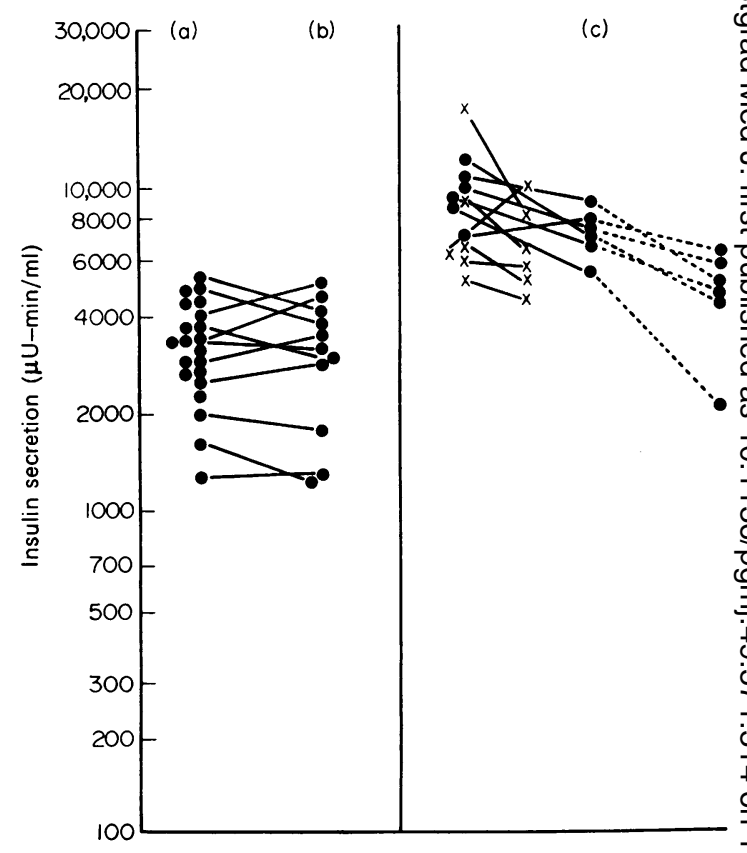

FIG. 2. Insulin secretion of: (a) twenty-one normal subjects, (b) the eleven normal subjects on whom a repeat test was performed, (c) twelve obese non-diabetic subjects, baseline and after therapy. alone; ..... diet plus fenfluramine; $\times-\frac{1}{\times} \times$ fenfluramine alone.

dietary restriction varying between 5 and 39 weeks. They showed a reduction in output of immunoreactive insulin during the oral glucose-tolerance $\stackrel{\varnothing}{\varnothing}$ test (OGTT) and a less marked reduction in the mean $\vec{\overrightarrow{ }}$ concentration of plasma glucose. Kalkhoff et al. $\exists$ (1971) studied six obese subjects given OGTTs before

TABLE 1. Statistical significance of dietary therapy alone and of dietary therapy plus fenfluramine on the glucose tolerance and insulin secretion of obese non-diabetic subjects when the results are compared with controls

\begin{tabular}{|c|c|c|c|c|c|}
\hline & \multicolumn{2}{|c|}{$\begin{array}{l}\text { Obese non-diabetic subjects on diet } \\
\text { alone for first } 10 \text { weeks }\end{array}$} & \multicolumn{2}{|c|}{$\begin{array}{l}\text { Obese non-diabetic subjects on diet } \\
\text { plus fenfluramine for second } \\
10 \text { weeks }\end{array}$} & \\
\hline & $\begin{array}{l}\text { Glucose } \\
\text { tolerance }\end{array}$ & $\begin{array}{l}\text { Insulin } \\
\text { secretion }\end{array}$ & $\begin{array}{l}\text { Glucose } \\
\text { tolerance }\end{array}$ & $\begin{array}{l}\text { Insulin } \\
\text { secretion }\end{array}$ & \\
\hline $\begin{array}{l}\text { Reproducibility of glucose tolerance in normal } \\
\text { subjects }\end{array}$ & NS $^{*}$ & - & $\begin{array}{l}\text { Marginally } \\
\text { significant } \\
0 \cdot 1>P>0.05\end{array}$ & - & 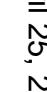 \\
\hline $\begin{array}{l}\text { Reproducibility of insulin secretion in normal } \\
\text { subjects }\end{array}$ & - & $\begin{array}{l}\text { Significant } \\
\text { decrease } \\
0.05>P>0.02\end{array}$ & - & $\begin{array}{l}\text { Significant } \\
\text { decrease } \\
P<0.02\end{array}$ & \\
\hline $\begin{array}{l}\text { Glucose tolerance of same obese patients on } \\
\text { diet alone for first } 10 \text { weeks }\end{array}$ & - & - & NS* & - & \\
\hline $\begin{array}{l}\text { Insulin secretion of same obese patients on } \\
\text { diet alone for first } 10 \text { weeks }\end{array}$ & - & - & - & $\begin{array}{l}\text { Significant } \\
\text { decrease } \\
P=0.05\end{array}$ & \\
\hline
\end{tabular}


and after a period of dietary restriction ranging from 10 to 18 months and involving an average weight loss of $85 \mathrm{lb}$ and a decrease from 83 to $27 \%$ above ideal body weight; associated with this, these workers showed a significant improvement in glucose tolerance and decrease in insulin secretion. In the subjects described here the diets were of similar calorific value and carbohydrate content to those in the two other investigations mentioned. During the 10-week period on diet alone, the weight losses ranged from 2 to $10 \mathrm{~kg}$, there was a trend towards improvement in glucose tolerance, and a significant fall in insulin secretion $(0.05>P>0.02)$. Hence, it would seem as if the reduction in insulin secretion occurs before the improvement in glucose tolerance as one of the metabolic effects of weight loss due to dietary restriction in obesity. The addition of fenfluramine to the dietary therapy would seem to accelerate the return of normal carbohydrate metabolism, since (1) 5 weeks on fenfluramine alone without dietary restriction brought about a significant improvement in glucose tolerance and a marginally significant decrease in insulin secretion, and (2) addition of fenfluramine to the dietary therapy for a further 10 weeks of treatment after treatment with dietary therapy alone, brought about a marginally significant improvement in glucose tolerance and a highly significant decrease in insulin secretion, the latter being significantly greater than that produced by diet alone in the same subjects. Fenfluramine has a similar effect to dietary restriction in reversing some of the abnormalities in carbohydrate metabolism in obesity and it appears to act more rapidly than does diet alone and to act very effectively when given together with dietary control.

It would seem that in situations of high insulin secretion, e.g. obesity and 'high-insulin-secreting' obese maturity-onset diabetes (Dykes, 1973), treatment with a low carbohydrate diet and fenfluramine is highly effective in lowering the level of insulin. It remains to be seen, however, if this effect is important therapeutically in view of the suggested association between high insulin concentrations and the development of atheroma (Stout \& Vallance-Owen, 1969).

\section{Acknowledgments}

Thanks are expressed to the late Professor P. Fourman for permission to study the patients under his care; to Professor G. H. Lathe for his constant encouragement and assistance; to Dr C. J. Hayter, Department of Nuclear Medicine at the General Infirmary, Leeds, for the use of the Phillips Counter; to Dr W. L. Burland, Medical Director of Servier Laboratories for advice and encouragement; to Mrs P. Petch and Mrs M. Collingwood for valuable technical assistance; to Miss Diana Whitehead for secretarial assistance; to Mr R. Cartwright for assistance with preparation of the figures for publication. This work was supported by grants from the British Diabetic Association and Servier Laboratories to whom thanks are expressed. The results were presented at the Fenfluramine Seminar in Nassau, 22-26 February 1971 and the Symposium on Obesity held at Cambridge in the Postgraduate Medical Centre on 6 May 1972.

\section{References}

Bagdade, J.D., Bierman, E.L. \& Porte, D. (1967) The significance of basal insulin levels in the evaluation of the insulin response to glucose in diabetic and non-diabetic subjects. Journal of Clinical Investigation, 46, 1549.

Burns, T.W., Bregant, R., van Peenan, H.J. \& Hood, T.E. (1965) Evaluation of the oral glucose tolerance test by a continuous sampling technique. Journal of Laboratory and Clinical Medicine, 65, 927.

Butterfield, W.J.H. \& Holling, H.E. (1959) Peripheral glucose metabolism in fasting control subjects and diabetic patients. Clinical Science, 18, 147.

CrADDOCK, D. (1969) In: Obesity and its Management, p. 80. E. \& S. Livingstone, Edinburgh.

DYKeS, J.R.W. (1973) The effect of a low calorie diet with and without fenfluramine on the glucose tolerance and insulin secretion of obese maturity-onset diabetics. Postgraduate Medical Journal, 49, 318.

Farrant, P.C., Nevjlle, R.W.J. \& Stewart, G.A. (1969) Insulin release in response to oral glucose in obesity; the effect of reduction of body weight. Diabetologia, $5,198$.

Hales, C.N. \& Randle, P.J. (1963) Immunoassay of insulin with insulin-antibody precipitate. Biochemical Journal, 88, 137.

von Herold, E., Kemper, F. \& OpITz, K. (1965) Einfluss appetithemmender substanzen auf kohlenhydrate und fettsäurestoffwechsel. Arzneimittel Forschung, 15, 657.

Kalkhoff, R.K., Kim, H.J., Cerletty, J. \& Ferrou, C.A. (1971) Metabolic effects of weight loss in obese subjects. Diabetes, 20, 83.

Morley, G., Dawson, A. \& Marks, V. (1968) Manual and AutoAnalyzer methods for measuring blood glucose using guaiacum and glucose oxidase. Proceedings of the Association of Clinical Biochemists, 5, 42.

Munro, J.F., Seaton, D.A. \& DunCan, L.J.P. (1966) Treatment of refractory obesity with fenfluramine. British Medical Journal, 2, 624.

NikKILÄ, F.A. \& TASKINEN, M.R. (1971)The insulin secretion rate in obesity. Postgraduate Medical Journal, 47, Suppl., 412.

Perley, M. \& Kipnis, D.M. (1965) Differential plasma insulin responses to oral and infused glucose in normal weight and obese non-diabetic and diabetic subjects. Journal of Laboratory and Clinical Medicine, 66, 1009.

Salans, L.B., Knitrle, J.L. \& Hirsch, J. (1968) The role of adipose cell size and adipose tissue insulin sensitivity in the carbohydrate intolerance of human obesity. Journal of Clinical Investigation, 47, 153.

SocIETY OF ACTUARIEs. (1959) In: Build and Blood Pressure Study, Vol. 1. Chicago.

SOKAL, R.R. \& Rohlf, F.J. (1969) In: Biometry, p. 391. W. H. Freeman and Co., San Francisco.

Stout, R.W. \& VAllanCE-OWEN, J. (1969) Insulin and atheroma. Lancet, i, 1078.

Turtle, J.R., Burgess, J.A. \& Bauckham, S. (1971) Forearm perfusion and intravenous infusion of fenfluramine in normal subjects. In: Fenfluramine Seminar, Pp. 185-199. Servier Laboratories Ltd.

Whichelow, M.J., Butterfield, W.J.H., Asmal, A.C., Boucher, B.J. \& Karamanos, B. (1971) Peripheral metabolism in obesity: the effect of weight reduction by diet and fenfluramine. In: Fenfluramine Seminar Addendum, Pp. 69-76. Servier Laboratories Ltd.

Yalow, R.S., GliCK, S.M., Roth, J. \& Berson, S.A. (1965) Plasma insulin and growth hormone levels in obesity and diabetes. Annals of the New York Academy of Sciences, $131,357$. 